\title{
Overweight and aerobic fitness in children in the United States/Mexico border region
}

\author{
Karen J. Coleman, ${ }^{1}$ Edward M. Heath, ${ }^{2}$ and Imelda S. Alcalá ${ }^{3}$
}

Suggested citation

Coleman KJ, Heath EM, Alcalá IS. Overweight and aerobic fitness in children in the United States/Mexico border region. Rev Panam Salud Publica. 2004;15(4):262-71.

\begin{abstract}
Objective. To study overweight and aerobic fitness among children in the third and fourth grades of elementary schools in a city in the United States of America (El Paso, Texas) and a city in Mexico (Chihuahua, Chihuahua) that are on or near the border between those two countries, and to compare the results from those two cities with earlier findings for other children in the United States.

Methods. We followed the El Paso children (427 boys and 385 girls, 93\% of them of Mexican descent) from third to fourth grade and assessed the change in their body mass index (BMI). In the city of Chihuahua we cross-sectionally measured the BMI of a sample of third grade children (221 boys and 237 girls) and a sample of fourth grade children (268 boys and 215 girls). BMI and triceps skinfolds were measured for all the children studied in the two cities. BMI was used to assess risk for overweight (at least the 85th percentile BMI for age and gender) and overweight (at least the 95th percentile BMI for age and gender) in all the children. The distance that El Paso children ran in nine minutes was used to assess their aerobic fitness (aerobic fitness was not measured in the Chihuahua children). The data from El Paso were collected in 1999, 2000, and 2001, and the Chihuahua data were collected in 2000 and 2001.

Results. In the El Paso boys, overweight significantly increased in the one year from third grade to fourth grade, from $22 \%$ to $28 \%$, while risk for overweight significantly increased, from $37 \%$ to $44 \%$. In the El Paso girls, risk for overweight significantly increased over the same oneyear period, from $29 \%$ to $37 \%$. The El Paso boys and girls were significantly less fit when compared to samples of children from throughout the United States. Third and fourth grade children from Chihuahua had similar rates of risk for overweight and of overweight when compared to the children from the same grades in El Paso.

Conclusions. Children in both El Paso and Chihuahua were more overweight than were non-Hispanic white children throughout the United States. In addition, the children in El Paso were less aerobically fit than were non-Hispanic white children and than were other MexicanAmerican children in the United States. These results clearly show that efforts should be made in the border regions of both Mexico and the United States to develop physical activity and nutrition programs to help stem rising rates of overweight.
\end{abstract}

Key words Child, anthropometry, obesity, physical fitness, Mexico, Mexican Americans.

1 San Diego State University, Graduate School of Public Health, San Diego, California, United States of America. Send correspondence to: Karen J. Coleman, Graduate School of Public Health, San Diego State University, 5500 Campanile Drive, San Diego, California 92182-4162, United States of America; telephone: 619-594-0559; fax: 619-5946112; e-mail: coleman@mail.sdsu.edu
2 Utah State University, Department of Health, Physical Education, and Recreation, Logan, Utah, United States of America.

3 Universidad Autónoma de Chihuahua, Facultad de Educación Física y Ciencias del Deporte, Chihuahua, Chihuahua, México.
While the impact that a healthy lifestyle has on coronary artery disease, obesity, and type 2 diabetes is well documented, that knowledge has not led to substantial changes in diet and physical activity in the United 
States of America (1-8). Only $22 \%$ of adults in the United States report regular sustained moderate to vigorous physical activity (for 30 minutes or more at least five times a week) $(2,8)$. In addition, poor dietary habits have contributed to $49 \%$ of the increase in risk for coronary artery disease in the United States over the past 10 years (1). High rates of inactivity and widespread consumption of high-calorie diets are most likely responsible for the high prevalence of obesity in adults worldwide (9-15) and also of overweight in children worldwide (16-22). Finally, lifestyle factors seem to be especially important in contributing to the high rates of type 2 diabetes in minority communities in the United States (23-28) and the appearance of type 2 diabetes in young children in the United States (28-31). Among Hispanic adults and children living in the United States, physical inactivity, overweight, and obesity are especially prevalent (5, 9, 20, 32-36).

The Hispanic population in the United States is the fastest growing minority group in the country. In the 2000 national population census 35.3 million people ( $12.5 \%$ of the total population of the United States) self-identified as Hispanic (37). By the year 2030 Hispanics will make up some $19 \%$ of the United States population (37). While $58.5 \%$ of the Hispanics in the United States are of Mexican heritage, the population also includes people of Puerto Rican, Cuban, Central American, and South American origins (37). The term "Hispanic" encompasses at least 17 distinct cultural groups from all over the world, with African, European, and indigenous ancestries (38). Some Hispanics are several generations removed from their country of origin, while others are the first generation to live in the United States (38). Approximately 35\% of Hispanics in the United States are under the age of 18 , compared to $26 \%$ for the rest of the population (37).

Because of the growing presence of Hispanics in the United States, especially children and young adults, health care priorities for them have become of increasing importance to the overall health of the country (39). In populations throughout the United States who are of Mexican descent, the majority of adults report no regular leisure-time moderate to vigorous physical activity $(8,32,33)$. In El Paso County, Texas, it is estimated that $33 \%$ of adult Hispanics are obese, and that the rate is 50\% among those over the age of $45 .{ }^{4,5}$ As a result of similar patterns around the United States, Hispanics are identified as a population in critical need of interventions to deal with physical inactivity and obesity, according to the Healthy People 2010 report of the United States Department of Health and Human Services (39). This report details goals to be accomplished by the year 2010 in order to improve the health of persons in the United States. The report covers a wide range of health concerns, including immunizations, physical activity, communicable diseases, obesity, and nutrition.

In recent years a number of researchers have suggested that overweight and obesity are becoming worldwide health concerns (40-42). In Mexico, for example, both adults (43-45) and children (17, 44, 45) are struggling with overweight. Investigators reported that the rates of overweight in young Mexican children (under 5 years old) are 19\% (45). In the United States more and more people of Mexican heritage are being assimilated into the health care system. Therefore, having data on the prevalence of overweight in Hispanic children and knowing how this compares to levels of overweight in Mexico and in the general population in the United States could provide useful insights into health problems from which Mexican-American children suffer as a result of excess body weight.

This article presents data on the prevalence of risk for overweight (at least the 85th percentile body mass index (BMI) for age and gender), overweight (at least the 95th percentile

\footnotetext{
4 Ramirez C. Diabetes awareness and education in the community: summary report April 2000 [unpublished manuscript]. 2000.

5 Condon KW, Pauli A, Price V, Fry B, Kaigh W, Kaigh G. El Paso health report 1996. Executive summary [unpublished manuscript]. 1997.
}

BMI for age and gender), and low aerobic fitness in children from third and fourth grades of elementary (primary) schools in El Paso, Texas, a city that is located on the border between Mexico and the United States. We compared the El Paso rates of risk for overweight and of overweight with data that we collected for children in third and fourth grade classes in schools in the city of Chihuahua, Chihuahua, Mexico. In addition, we compared the El Paso data with United States national standard rates for acceptable aerobic fitness, prevalence of overweight, and prevalence of risk for overweight for non-Hispanic white and Mexican-American children 6 to 11 years old (20).

The data from the United States national samples of non-Hispanic white children and of Mexican-American children came from the National Health and Nutrition Examination Survey (NHANES) and the Hispanic Health and Nutrition Examination Survey (HHANES), which have tracked a variety of adult and children's health outcomes for the last 15 years (20-22, 46-48). Data on aerobic fitness came from nationwide United States standardized tests (49) as well as from research conducted in the city of San Antonio, Texas (50).

Other researchers have presented prevalence data on risk for overweight and on overweight for larger numbers of Hispanic children $(21,22,51)$ than we present in this study. However, our data set on children in El Paso (93\% of them Hispanic) is one of the largest data sets representing primarily children of Mexican descent. Further, our study was conducted in a city that has several noteworthy characteristics, including a noticeable presence of families of very low income (37) and a dominant Mexican culture, with more than three-quarters of the city's some 564000 residents self-identifying as Hispanic in the 2000 census (37). El Paso ranks sixth among cities in the United States in terms of the number of Hispanic residents (37). A bridge across the Rio Grande river connects the downtown of El Paso with the city of Ciudad Juárez, Chihuahua, Mexico. 
The other city where we collected information on school children, Chihuahua, Chihuahua, Mexico, had a 2002 population of 708269 people. Chihuahua is located around 220 miles (354 km) south of El Paso and Ciudad Juárez.

\section{METHODS}

\section{El Paso participants}

The initial participants from the United States were 901 third grade children in eight elementary schools in El Paso, Texas. These schools were randomly selected from two school districts as part of a longitudinal study of children's health (third through fifth grades) in El Paso. The El Paso children who participated in this study were predominantly Hispanic (93\%). Approximately $82 \%$ to $92 \%$ of the children in these eight schools were eligible for free or reduced-cost meals or were receiving some other forms of assistance for food and living expenses from programs of the United States Government, and $33 \%$ to $72 \%$ of the children had limited English proficiency. All the schools in El Paso were public schools.

Information about the study was sent to the parents, grandparents, or other legal guardians of all third grade children in the eight elementary schools by mailing consent forms or having the children take the consent forms home to those adults. The adults had to indicate on a form if they did not want their children to participate in the study and mail this form back to the investigators or send the form back to their third grade child's school. All information about the study was provided in Spanish and English. Ninetyfour percent of the parents of the third grade children in the eight elementary schools agreed to have their child participate in the study.

The El Paso children were followed into fourth grade. All data presented in this report reflect children who were available in the third grade and also one year later in fourth grade $(n=$ 812; 427 boys and 385 girls). Ten per- cent of children were lost to follow-up (that is, from the third grade to fourth grade) because they moved out of the El Paso area or they could not be located in any of the El Paso school systems. No children and none of their families withdrew from the study after giving consent in the initial, thirdgrade year. Approval for the project was obtained from the Institutional Review Board at the University of Texas at El Paso (where the authors were at when the study was done).

\section{Chihuahua participants}

The participants in Chihuahua, Chihuahua, were 458 third grade students ( 221 boys and 237 girls) and 483 fourth grade children (268 boys and 215 girls) selected from 10 elementary schools in the city, using matched random sampling as part of a project that assessed the validity of Spanish self-efficacy questionnaires. The elementary schools in Chihuahua were matched to the general characteristics of the schools from the El Paso sample, that is, having physical education classes, one teacher per 25 to 30 children, and classroom supplies and books for all children. Generally, the schools chosen were middle or upper class public or private schools.

Information about the study was sent to the parents, grandparents, or other legal guardians of all third and fourth grade children in the 10 schools by mailing consent forms or having the children take the consent forms home to those adults. The adults had to indicate on a form if they did not want their children to participate in the study and mail this form back to the investigators or send the form back to each child's school. Consent was obtained from third and fourth grade children in the 10 schools at the time of measurement. There was a $100 \%$ participation rate.

Approval for the project was obtained from the Institutional Review Board at the University of Texas at El Paso and also from the Institutional Review Board of the Autonomous University of Chihuahua (Universidad Autónoma de Chihuahua).

\section{Measurements}

Aerobic fitness (El Paso only). With the El Paso students only, aerobic fitness was assessed with a nine-minute timed run. Luepker et al. (52) reported a test-retest reliability correlation for this procedure of 0.90 in third grade students from the Child and Adolescent Trial for Cardiovascular Health (CATCH) program, which was conducted in four cities in the United States. In another study, carried out in the city of Austin, Texas, Turley and colleagues (53) demonstrated a testretest correlation of 0.89 for 24 third grade boys and 0.90 for 26 third grade girls for the nine-minute timed run.

Anthropometry (both cities). In both El Paso and Chihuahua, the anthropometry measurements for third and fourth grade students included height, weight, and triceps skinfolds. At least three people were trained in El Paso and Chihuahua to collect these measures, using a sample of 100 young adults and 50 children. Each person's measurements were compared to an experienced technician's values, and reliability was established at a minimum of 0.90 for height, weight, and triceps skinfolds before data collection. This experienced technician trained all personnel in both El Paso and Chihuahua. During the fourth grade follow-up in the El Paso sample, reliability was established at 0.90 or above for all measures on a small subsample (30 children) before data collection began.

Children removed their shoes and any heavy clothing before having their weight measured to the nearest $0.25 \mathrm{lb}$ $(0.11 \mathrm{~kg})$ on a portable, digital, legal weights and measures calibrated scale (Tanita Corporation, Evanston, Illinois, United States). Height was measured to the nearest 0.13 in $(0.32 \mathrm{~cm})$ using a cloth tape measure fixed to a flat wall surface. Body mass index (BMI) was calculated by dividing weight $(\mathrm{kg})$ by height squared $\left(\mathrm{m}^{2}\right)$.

Triceps skinfolds on the right side of the body were assessed using Lange calipers (Cambridge Scientific 
Industries, Inc., Cambridge, Maryland, United States) while children stood relaxed and with their arms at their sides. The triceps skinfold was measured vertically, midway between the acromion process of the scapula and the bottom of the olecranon process of the ulna. Three measures at the site were taken and these values were added and averaged for a final triceps skinfolds value (54). Luepker et al. (52) reported intraclass correlations of 0.97 for this skinfold method across students who participated in the United States CATCH study in third, fourth, and fifth grades.

\section{Procedures}

In both El Paso and Chihuahua the measurements were taken during school hours, either during physical education or academic class time. Before any measurements were taken, procedures were explained to each child, and each child had to indicate his or her understanding of the procedures and willingness to participate in the study. The nine-minute run was conducted with groups of 20 to 40 children in the El Paso sample outside, on a flat surface, around a 200-yard (182.8-m) "track" made of nylon rope with cone markers every 20 yards $(18.28 \mathrm{~m})$. Children received a small stick each time they completed one 200-yard lap around the track. At the end of nine minutes, all sticks were counted and recorded for each child.

Anthropometry was assessed in both the El Paso and Chihuahua samples by collecting groups of five children. Body composition was measured privately for each child so that the other children could not see his or her values. Aerobic fitness and body composition were collected on different days for the El Paso children, so not all of the El Paso children had both fitness and body composition data since some children were absent from school the day of one of the measures. Three attempts on different days were made to obtain both measures for every child in the sample during a three-month sampling interval.

\section{Health classifications and analyses}

The El Paso height, weight, skinfolds, and distance run are presented as the mean ( \pm standard deviation), and the rates of overweight, risk for overweight, and passing distance-run standards are presented as percentages. The Chihuahua height, weight, and skinfolds are presented as mean ( \pm standard deviation), and rates of overweight and risk for overweight are presented as percentages. As mentioned earlier in this article, the El Paso and Chihuahua rates of overweight are compared to overweight prevalence data from NHANES and HHANES (20-22, 46-48).

We compared our El Paso aerobic fitness data to findings from third and fourth grade Mexican-American children in the city of San Antonio, Texas (50), and to third and fourth grade non-Hispanic white children from throughout the United States (49). Aerobic fitness was determined by comparing the distance run in nine minutes to the standards set by the FITNESSGRAM run test. FITNESSGRAM is a United States testing system for physical educators to use in assessing various indicators of fitness in children from kindergarten to high school (www.fitnessgram.com). The system has been widely adopted by United States national physical fitness organizations. It is recommended that schools have $70 \%$ or more of the children in a grade level pass each test for aerobic, strength, and flexibility fitness.

There has been some controversy in the United States concerning using the word "obesity" with children because of the negative connotations and prejudice associated with this term. The Centers for Disease Control and Prevention (CDC) of the United States has suggested new terminology to avoid labeling children as "obese" (55). This terminology accompanies a new set of guidelines for the assessment of a child's appropriate weight in relation to normal growth $(55,56)$. Under the new terminology, children are defined as "at risk for overweight" if they have a BMI that is at or above the 85th percentile rank for children of the same age and gender, while "overweight" (instead of obese) is defined as having a BMI that is at or above the 95th percentile rank for children of the same age and gender. Data for these definitions came from several nationwide health surveillance systems in the United States that track the growth of children from kindergarten through high school (55, 56; see also www.cdc.nchs.org).

Throughout our article, risk for overweight will be abbreviated as "ROV," and overweight will be abbreviated as "OV." ROV for third grade boys was at or above a BMI of $18.60 \mathrm{~kg} / \mathrm{m}^{2}$, and ROV for third grade girls was at or above a BMI of $19.20 \mathrm{~kg} / \mathrm{m}^{2}$. OV for third grade boys was at or above a BMI of $21.10 \mathrm{~kg} / \mathrm{m}^{2}$, and OV for third grade girls was at or above a BMI of 21.80 $\mathrm{kg} / \mathrm{m}^{2}$. ROV for fourth grade boys was at or above a BMI of $19.40 \mathrm{~kg} / \mathrm{m}^{2}$, and ROV for fourth grade girls was at or above a BMI of $20.00 \mathrm{~kg} / \mathrm{m}^{2}$. OV for fourth grade boys was at or above a BMI of $22.10 \mathrm{~kg} / \mathrm{m}^{2}$, and OV for fourth grade girls was at or above a BMI of $23.00 \mathrm{~kg} / \mathrm{m}^{2}$.

Aerobic fitness data for the El Paso children are compared to performance on the FITNESSGRAM $(49,50)$ onemile $(1.609 \mathrm{~km})$ run using the following formula: passing for nine-minute run in yards ( 1 yard $=0.914 \mathrm{~m}$ ) for third grade boys $=(1760$ yards $/ 13$ minutes) $\times 9$ minutes, which is 1218 yards (1 $114 \mathrm{~m}$ ) completed in nine minutes; passing for nine-minute run in yards for third grade girls $=(1760 / 14$ minutes) $\times 9$ minutes, which is 1131 yards $(1034 \mathrm{~m})$ completed in nine minutes. The cutoff for passing the nineminute run in fourth grade boys was 1320 yards (1 $206 \mathrm{~m})$, and in fourth grade girls it was 1218 yards (1 $113 \mathrm{~m})$.

We examined the differences from third to fourth grade for the El Paso boys and the El Paso girls in distance run, BMI, and triceps skinfolds, using mixed analysis of variance (ANOVA) with a between-subjects factor of gender and a within-subjects factor of time. We examined the differences between the third grade boys and girls in El Paso and the third grade boys and girls in Chihuahua for BMI and triceps skinfolds using factorial ANOVA with 
TABLE 1. Characteristics (mean \pm standard deviation) of children studied in the cities of El Paso, Texas, United States, 1999-2001, and Chihuahua, Chihuahua, Mexico, 2000-2001

\begin{tabular}{|c|c|c|c|c|c|c|c|c|}
\hline & \multicolumn{2}{|c|}{ 3rd grade boys } & \multicolumn{2}{|c|}{ 4th grade boys } & \multicolumn{2}{|c|}{ 3rd grade girls } & \multicolumn{2}{|c|}{ 4th grade girls } \\
\hline & El Paso & Chihuahua & El Paso & Chihuahua & El Paso & Chihuahua & El Paso & Chihuahua \\
\hline Age (yr) & $8.4 \pm 0.5$ & $\ldots^{a}$ & $9.6 \pm 0.6$ & & $8.4 \pm 0.5$ & & $9.5 \pm 0.5$ & \\
\hline Weight (kg) & $32.9 \pm 9.1$ & $33.2 \pm 8.3$ & $38.7 \pm 11.3$ & $36.9 \pm 8.9$ & $31.6 \pm 8.4$ & $31.5 \pm 7.1$ & $37.8 \pm 10.7$ & $36.5 \pm 9.7$ \\
\hline BMI $\left(\mathrm{kg} / \mathrm{m}^{2}\right)$ & $18.55 \pm 4.03$ & $18.49 \pm 3.66$ & $20.02 \pm 4.62$ & $19.12 \pm 3.55$ & $18.06 \pm 3.59$ & $17.93 \pm 2.99$ & $19.39 \pm 4.14$ & $19.00 \pm 3.89$ \\
\hline Triceps (mm) & $15.14 \pm 7.05$ & $12.87 \pm 6.29$ & $16.40 \pm 8.43$ & $13.75 \pm 6.05$ & $17.03 \pm 6.28$ & $13.80 \pm 5.71$ & $16.63 \pm 7.06$ & $14.92 \pm 6.23$ \\
\hline
\end{tabular}

a The ellipsis points (...) indicate that these data were not collected for the Chihuahua sample.

one between-subjects variable of gender and another of country. A similar analysis was done for the fourth grade boys and girls in the two cities.

We used the chi-square $\left(\chi^{2}\right)$ statistic for proportional data to compare the ROV and OV prevalence rates for the El Paso children with the following samples: (1) the published national rates for non-Hispanic white children and Mexican-American children 6-11 years old throughout the United States from NHANES and HHANES (20), and (2) the rates of ROV and OV for the Chihuahua children. We calculated Pearson's correlations $(r)$ between BMI and triceps skinfolds, BMI and aerobic fitness, and triceps skinfolds and aerobic fitness for the El Paso sample to demonstrate the relationships among these variables in this sample of children.

\section{RESULTS}

In the tables and text sections below we present the summary results of our findings from El Paso and Chihuahua, comparisons between the students in El Paso and the students in Chihuahua, and comparisons between the students in those two cities and students elsewhere in the United States. The overall characteristics for the El Paso and Chihuahua sample will be provided in Table 1. Table 2 will show the passing rates for aerobic fitness of El Paso children in third and fourth grades compared to nationwide United States samples of non-Hispanic white children and Mexican-American chil-

TABLE 2. Rates of passing aerobic fitness timed-run test, of risk for overweight (ROV), and of overweight (OV) in El Paso, Texas, United States, 1999-2001, and in Chihuahua, Chihuahua, Mexico, 2000-2001, as compared to other groups of children in the United States

\begin{tabular}{|c|c|c|c|c|}
\hline \multirow[b]{2}{*}{ Rates of passing FITNESSGRAM ${ }^{a}$} & \multicolumn{2}{|c|}{ Boys } & \multicolumn{2}{|c|}{ Girls } \\
\hline & & & & \\
\hline El Paso 3rd grade (mean age, 8.4 years) & $59 \%$ & $(n=414)$ & $55 \%$ & $(n=365)$ \\
\hline El Paso 4th grade (mean age, 9.6 years) & $60 \%$ & $(n=414)$ & $69 \%$ & $(n=365)$ \\
\hline San Antonio, Texas, Mexican-American sample of 8-year-olds (50) & $78 \%$ & $(n=49)$ & $81 \%$ & $(n=47)$ \\
\hline San Antonio, Texas, Mexican-American sample of 9-year-olds (50) & $58 \%$ & $(n=41)$ & $69 \%$ & $(n=46)$ \\
\hline United States national non-Hispanic white sample of 8 -year-olds (49) & $84 \%$ & $(n=231)$ & $85 \%$ & $(n=245)$ \\
\hline United States national non-Hispanic white sample of 9-year-olds (49) & $81 \%$ & $(n=261)$ & $80 \%$ & $(n=215)$ \\
\hline \multicolumn{5}{|l|}{ Rates of risk for overweight (ROV) ${ }^{b}$} \\
\hline El Paso 3rd grade (mean age, 8.4 years old) & $37 \%$ & $(n=427)$ & $29 \%$ & $(n=385)$ \\
\hline El Paso 4th grade (mean age, 9.6 years old) & $44 \%$ & $(n=427)$ & $37 \%$ & $(n=385)$ \\
\hline Chihuahua 3rd grade (age unavailable) & $39 \%$ & $(n=221)$ & $27 \%$ & $(n=237)$ \\
\hline Chihuahua 4th grade (age unavailable) & $39 \%$ & $(n=265)$ & $33 \%$ & $(n=215)$ \\
\hline United States national non-Hispanic white sample of children 6-11 years old (20) & $29 \%$ & $(n=120)$ & $23 \%$ & $(n=122)$ \\
\hline United States national Mexican-American sample of children 6-11 years old (20) & $43 \%$ & $(n=229)$ & $35 \%$ & $(n=194)$ \\
\hline \multicolumn{5}{|l|}{ Rates of overweight $(\mathrm{OV})^{\mathrm{c}}$} \\
\hline El Paso 3rd grade (mean age, 8.4 years old) & $22 \%$ & $(n=427)$ & $16 \%$ & $(n=385)$ \\
\hline El Paso 4th grade (mean age, 9.6 years old) & $28 \%$ & $(n=427)$ & $18 \%$ & $(n=385)$ \\
\hline Chihuahua 3rd grade (age unavailable) & $20 \%$ & $(n=221)$ & $11 \%$ & $(n=237)$ \\
\hline Chihuahua 4th grade (age unavailable) & $23 \%$ & $(n=265)$ & $16 \%$ & $(n=215)$ \\
\hline United States national non-Hispanic white sample of children 6-11 years old (20) & $12 \%$ & $(n=120)$ & $12 \%$ & $(n=122)$ \\
\hline United States national Mexican-American sample of children 6-11 years old (20) & $27 \%$ & $(n=229)$ & $20 \%$ & $(n=194)$ \\
\hline
\end{tabular}

a Aerobic fitness was determined by comparing the distance run in nine minutes to the standards set by the FITNESSGRAM run test. FITNESSGRAM is a United States testing system for physical educators to use in assessing various indicators of fitness in children from kindergarten to high school. It is recommended that schools have $70 \%$ or more of the children in a grade level pass each test for aerobic, strength, and flexibility fitness.

${ }^{\mathrm{b}}$ Risk for overweight (ROV) = body mass index that is at or above the 85th percentile rank for children of the same age and gender.

${ }^{c}$ Overweight $(\mathrm{OV})=$ body mass index that is at or above the 95th percentile rank for children of the same age and gender. 
dren 6-11 years of age. Table 2 will also show ROV and OV rates for $\mathrm{El}$ Paso and Chihuahua children in third and fourth grades compared to ROV and OV rates for nationwide United States samples of non-Hispanic white and Mexican-American children 6-11 years of age.

\section{El Paso sample}

The large majority of the students in the El Paso sample were Hispanic. Of the boys, $94.0 \%$ were Hispanic, 3.0\% were non-Hispanic white, $0.2 \%$ were black, and 2.8\% were either "other" (such as Native American, Asian, or Pacific Islander) or of unidentified ethnicity. Of the girls, $91.0 \%$ were Hispanic, $2.0 \%$ were non-Hispanic white, $1.0 \%$ were black, and $6.0 \%$ were either "other" or unidentified. Children were in third grade at the beginning of the study and then followed into fourth grade, thus the majority were between 8 and 10 years of age (Table 1 ).

El Paso boys ran farther than did El Paso girls in both the third grade and the fourth grade $\left(\mathrm{F}_{1,666}=40.37 ; P<\right.$ 0.001). El Paso boys also had higher BMI values than did El Paso girls in both grades $\left(\mathrm{F}_{1,692}=5.33 ; P=0.02\right)$ (Table 1). El Paso girls and boys ran farther $\left(\mathrm{F}_{1,666}=307.93 ; P<0.001\right)$ and weighed more $\left(\mathrm{F}_{1,692}=767.51 ; P<\right.$ 0.001 ) in fourth grade than they did in third grade (Table 1). There was an interaction of gender and grade with respect to triceps skinfolds $\left(\mathrm{F}_{1,693}=40.49\right.$; $P<0.001$ ), with the boys' triceps skinfolds significantly increasing from third to fourth grade (15.14 mm vs. $16.40 \mathrm{~mm} ; P<0.001)$, while the girls' measurements did not increase (17.03 mm vs. $16.63 \mathrm{~mm} ; P=0.24$ ) (Table 1 ).

Passing rates for aerobic fitness in $\mathrm{El}$ Paso girls increased significantly from third to fourth grades (55\% to 69\%; $\chi_{1}^{2}=11.46 ; P<0.001$ ) (Table 2). However, there was no significant change in passing FITNESSGRAM standards for aerobic fitness in boys from third to fourth grades (59\% to 60\%) (Table 2). The prevalence of ROV significantly increased in El Paso girls from third to fourth grade ( $29 \%$ to $37 \% ; \chi_{1}^{2}=8.035$;
$P<0.01$ ); however, the prevalence of $\mathrm{OV}$ in girls did not change significantly in this time frame (16\% to $18 \%$ ) (Table 2). For boys, both the prevalence of $\operatorname{ROV}$ ( $37 \%$ to $44 \% ; \chi_{1}^{2}=4.79$; $P<0.01)$ and the prevalence of $\mathrm{OV}$ (22\% to $\left.28 \% ; \chi_{1}^{2}=7.19 ; P<0.01\right)$ significantly increased from the third grade to the fourth grade.

Both BMI and triceps skinfolds were moderately inversely correlated with distance run in nine minutes for girls (BMI, $r=-0.48$; triceps, $r=-0.46$ ) and for boys (BMI, $r=-0.38$; triceps, $r=$ $-0.39)$. Both BMI and triceps skinfolds were highly and directly correlated with each other for girls $(r=0.90)$ and for boys $(r=0.86)$.

\section{Chihuahua sample}

The overall characteristics of the Chihuahua sample are shown in Table 1. Table 2 shows the percentage of third and fourth grade Chihuahua boys and girls who were ROV and the percentage of third and fourth grade boys and girls who were OV.

In Chihuahua the third grade girls were not significantly different from the third grade boys with respect to BMI or triceps skinfolds (Table 1). Fourth grade boys and girls had BMI values that were similar to each other, but fourth grade girls had significantly higher triceps skinfolds than did fourth grade boys (14.92 mm vs. 13.75 $\mathrm{mm} ; \mathrm{F}_{1,481}=4.31 ; P=0.038$ ) (Table 1 ).

Compared to third grade El Paso children, Chihuahua children had lower triceps skinfolds $\left(\mathrm{F}_{1,1347}=54.34\right.$; $P<0.001)$. For fourth graders, Chihuahua children had lower BMI $\left(\mathrm{F}_{1,1299}=7.33 ; P=0.007\right)$ and lower triceps skinfolds $\left(\mathrm{F}_{1,1300}=27.39 ; P<\right.$ $0.001)$ when compared to El Paso children (Table 1).

\section{Prevalence rates of overweight and of risk of overweight in El Paso vs. Chihuahua}

For the third grade students there were no significant differences in the prevalence of ROV between boys in
Chihuahua and boys in El Paso (39\% vs. $37 \%$ ) or for prevalence of ROV between the girls in the two cities $(27 \%$ vs. 29\%) (Table 2). In addition, for the third grade boys, there was no significant difference in prevalence rates for OV between Chihuahua (20\%) and El Paso (22\%) (Table 2). However, third grade El Paso girls had significantly higher OV prevalence rates $(16 \%)$ than did third grade Chihuahua girls (11\%) $\left(\chi_{1}^{2}=4.45 ; P<0.05\right)$ (Table 2). There were no significant differences in the prevalence of ROV between fourth grade El Paso boys (44\%) and fourth grade Chihuahua boys (39\%), or between fourth grade El Paso girls (37\%) and fourth grade Chihuahua girls $(33 \%)$ (Table 2). There were also no significant differences between OV prevalence rates of fourth grade boys in El Paso (28\%) and in Chihuahua $(23 \%)$, or between the fourth grade girls in El Paso (18\%) and in Chihuahua (16\%) (Table 2).

\section{Aerobic fitness in El Paso vs. children nationwide in the United States}

Table 2 shows passing rates for FITNESSGRAM aerobic fitness for children in El Paso. Third grade El Paso girls had significantly lower passing rates for aerobic fitness $(55 \%)$ compared to third grade MexicanAmerican girls in a sample from San Antonio, Texas $(81 \%)\left(\chi_{1}^{2}=30.49 ; P<\right.$ 0.001 ), and compared to a nationwide United States sample of non-Hispanic white third grade girls $(85 \%)\left(\chi_{1}^{2}=\right.$ 38.33; $P<0.001)$. The results were similar for third grade El Paso boys, who had significantly lower aerobic fitness passing rates $(59 \%)$ when compared to third grade Mexican-American boys in San Antonio (78\%) $\left(\chi_{1}^{2}=19.81 ; P<\right.$ 0.001 ) and when compared to a United States nationwide sample of nonHispanic white boys in third grade $(84 \%)\left(\chi_{1}^{2}=31.68 ; P<0.001\right)$.

For fourth grade children there were no significant differences in passing rates for aerobic fitness between El Paso girls (69\%) when compared to San Antonio Mexican-American fourth 
grade girls $(69 \%)$ and between El Paso boys $(60 \%)$ and San Antonio MexicanAmerican fourth grade boys (58\%). However, when compared to a nationwide United States sample of fourth grade non-Hispanic white children, El Paso girls had significantly lower passing rates for aerobic fitness $(69 \%$ vs. $80 \%)\left(\chi_{1}^{2}=6.33 ; P<0.01\right)$, as did the El Paso boys $(60 \%$ vs. $81 \%)\left(\chi_{1}^{2}=22.08\right.$; $P<0.001)$.

\section{Prevalence rates of overweight and of risk of overweight in El Paso vs. United States national samples}

Table 2 shows ROV and OV prevalence rates for $\mathrm{El}$ Paso children in third grade and then again when they were in fourth grade, Cuidad Chihuahua third and fourth grade children, and United States nationwide samples of children 6-11 years of age. The United States nationwide samples are shown for non-Hispanic white children and Mexican-American children. Compared to nationwide United States samples of Mexican-American boys (43\% ROV and 27\% OV) (20), El Paso boys had similar rates of ROV (37\%, third grade; $44 \%$, fourth grade) and of OV $(22 \%$, third grade; $28 \%$, fourth grade). However, when compared to nationwide United States samples of non-Hispanic white boys (29\% ROV and $12 \%$ OV) (20), El Paso third grade boys had similar rates of ROV (37\%) but were significantly more overweight $(22 \%)\left(\chi_{1}^{2}=10.29 ; P<0.001\right)$. When El Paso boys were in fourth grade they had a significantly higher prevalence of $\operatorname{ROV}(44 \%)\left(\chi_{1}^{2}=9.26\right.$; $P<0.01)$, and OV $(28 \%)\left(\chi_{1}^{2}=28.57\right.$; $P<0.001)$ when compared to this same nationwide United States sample of non-Hispanic white boys (29\% ROV and $12 \%$ OV) (20).

As shown in Table 2, El Paso third grade girls had similar rates of $\mathrm{ROV}$ (29\%) and OV (16\%) as compared to nationwide United States samples of Mexican-American girls $(35 \% \mathrm{ROV}$ and 20\% OV) (20). These similarities were maintained when the El Paso girls became fourth graders $(37 \% \mathrm{ROV}$ and $18 \% \mathrm{OV})$. When compared to na- tionwide United States samples of non-Hispanic white girls $(23 \% \mathrm{ROV}$ and $12 \% \mathrm{OV}$ ), the El Paso third grade girls were similar with respect to ROV (29\%) and to OV (16\%). However, when these El Paso girls became fourth graders, they had a significantly higher prevalence of ROV $(37 \%)\left(\chi_{1}^{2}=10.32\right.$; $P<0.001)$ when compared to the same nationwide United States sample of non-Hispanic white girls. Rates of OV for fourth grade El Paso girls (18\%) remained similar to those for the nationwide United States sample of nonHispanic white girls.

\section{DISCUSSION}

Our results clearly show that the third grade children whom we studied in El Paso were more unfit, were more overweight, and had higher body fat in comparison to non-Hispanic white children from other regions of the United States (20-22, 46-48). In addition, the El Paso children were more unfit than a sample of Mexican-American children in San Antonio, Texas (50). The high rates of risk for overweight and of overweight in El Paso were primarily due to body fat. El Paso children had higher triceps skinfolds as compared to nationwide United States findings for non-Hispanic white children of similar age (46). These findings were still evident and even more pronounced when the El Paso children were measured in fourth grade. Rates of risk for overweight increased in one year by $7 \%$ in El Paso boys and 8\% in El Paso girls, and rates of overweight increased in the same year by $6 \%$ in El Paso boys and 2\% in El Paso girls. These patterns in El Paso mirror trends in child risk for overweight and overweight seen in many countries around the world (57).

The children studied in Chihuahua were similar to the children in El Paso in terms of their prevalence of risk for overweight and of overweight. While this sample of Mexican children had significantly lower triceps skinfold thicknesses than did the children in El Paso, the Chihuahua children still had higher skinfold thickness values as compared to national United States findings for non-Hispanic white children of similar age (Table 1) (46). These data clearly support the view that Mexico is developing a problem with childhood overweight that, while not on the order of magnitude seen in the United States, is becoming a public health concern $(44,45)$.

The high rates of overweight and low rates of aerobic fitness in the El Paso sample may be due to the fact that preventive, healthy behaviors are not common in the United States/ Mexico border area of El Paso and Chihuahua. For instance, recent communitywide surveys conducted by an El Paso health foundation found that most adults living in El Paso County had consumed an average of 10 servings of fat per day in 2000, $70 \%$ of $\mathrm{El}$ Paso adults had not engaged in any regular moderate to vigorous physical activity in $1996,{ }^{6}$ and $45 \%$ of El Paso adults had reported no moderate to vigorous physical activity at all in $2000 .^{7}$ In our sample of El Paso third graders, no children reported doing vigorous physical activity outside of school, and only $27 \%$ reported some vigorous physical activity in school. ${ }^{8}$ Inactivity and poor nutrition are factors contributing to the "obesity epidemic" across the United States (57). Mexican-American families, however, may be particularly susceptible to obesity, with a diet high in simple sugars and starches such as bread and tortillas $(58,59)$, a lack of regular moderate to vigorous exercise outside of work $(32,33)$, and parenting styles that are less restrictive in terms of their children's food intake (60).

It is unclear why Mexico and other countries that have traditionally strug-

\footnotetext{
6 Condon KW, Pauli A, Price V, Fry B, Kaigh W, Kaigh G. Paso del Norte Health Foundation: El Paso health report 1996 executive summary [Unpublished manuscript]. 1997.

7 Ramirez C. Diabetes awareness and education in the community: summary report April 2000 [unpublished manuscript]. 2000.

8 Coleman KJ, Heath EM, Alcala IS, Barron F, Gonzalez EC, Pope RP. The need for children's health prevention programs on the U.S./Mexico border region: baseline data from the El Paso Coordinated Approach to Child Health. Ann Beh Med. 2001; 23(Suppl.):S88.
} 
gled with undernutrition are now finding themselves with a developing obesity epidemic (17, 40, 41, 43-5). There is evidence that watching television is linked to childhood obesity in Mexico (17) and that there is a growing presence of inexpensive fast food chain restaurants in countries around the world (44). In addition, urban areas are associated with high obesity rates in Mexico (44) as well as a transition to a more middle-class way of life with the increasing globalization of the world economy $(17,44)$.

Both the third grade El Paso boys and girls had lower rates of passing (58\% and 53\%, respectively) the timed distance-run standard when compared to nationwide United States samples of non-Hispanic white boys $(81 \%)$ and girls (80\%) (49) (Table 2). Third grade El Paso boys and girls also had lower rates of passing (57\% and $53 \%$, respectively) the distance-run standard than did a sample of Mexican-American boys (78\% passing) and Mexican-American girls (81\% passing) in the city of San Antonio, Texas (50) (Table 2). Third grade children from the national CATCH study (14\% Hispanic) ran $13 \%$ farther than did the El Paso boys and 22\% farther than did the El Paso girls (51). Nine-minute run results were also reported for a small sample of third grade boys and girls (31\% Hispanic) from the CATCH site in the city of Austin, Texas (53). The Austin third grade boys ran 19\% farther than the El Paso third grade boys did, and the Austin third grade girls ran 25\% farther than the El Paso third grade girls did.

The data from our study are not meant to represent all Mexican-Amer- ican elementary school children living along the United States/Mexico border nor all children living in large cities in Mexico similar to Chihuahua. Most of the children in the El Paso sample qualified for free or reducedcost school meals or were receiving some other form of government aid for food and living expenses. Therefore, the high rates of overweight in our El Paso sample might reflect an effect of poverty rather than of ethnicity. Strauss and Pollack (61) recently reported that ethnicity combined with low income resulted in the highest rates of overweight among children throughout the United States in the Longitudinal Survey of Youth, with the rate being $27 \%$ in low-income Hispanic boys in 1998. This rate is very similar to the $28 \%$ that we found for fourth grade El Paso boys. In order to match our school samples in Mexico and in the United States, the children in Chihuahua were from middle or upper class socioeconomic levels. There is some support in the scientific literature for a positive relationship between socioeconomic status and body weight in Mexico, with child and adult obesity rates being highest among higher-income families from urban areas (44).

There is some controversy about the use of standardized aerobic fitness tests to assess the physical fitness of children or to determine if they are regularly physically active $(62,63)$. The setting of a standard level of "passing" is somewhat subjective and does not take into account ethnic differences in aerobic fitness. In addition, running tests might underestimate the aerobic fitness of overweight children due to the fact that these children are not very efficient runners (64). However, standardized aerobic fitness run tests are preferred to general activity level because the results are independent of the population distribution and the emphasis is on health-related levels of fitness (62). In addition, the evidence of the appropriateness of the nine-minute run for cardiorespiratory fitness in children is well documented $(52,53)$.

Our study is one of the largest to assess risk for overweight, overweight, and aerobic fitness in children of Mexican descent in the United States and the first two of those characteristics among children in Mexico. Our study provides evidence that a problem with child overweight is beginning in Mexico, which could substantially affect the health of children in the United States, especially along the United States/Mexico border. Finally, our findings clearly establish a need for community-based physical activity and nutrition programs for young Mexican-American children living in the United States along the United States/Mexico border and for similar efforts in children in the northern border states of Mexico in order to arrest the beginning stages of an epidemic increase in child overweight.

Acknowledgements. This work was funded by the Patient Care and Outcomes Research Award program from the American Heart Association (\#9970182N). The authors would like to thank Sherrie Jewell, Klaus Hille, Tommy Tinajero, Eugenia Gonzalez, Roman Pope, Felix Barron, Peter Cribb, Deanna Hoelscher, and Elaine Stone for all their support.

\section{REFERENCES}

1. American Heart Association. 2000 heart and stroke statistical update. Dallas: American Heart Association; 1999.

2. NIH Consensus Development Panel on Physical Activity and Cardiovascular Health. Physical activity and cardiovascular health. JAMA. 1996;276:241-6.
3. Paffenbarger RS Jr, Hyde RT, Wing AL, Lee IM, Jung DL, Kampert JB. The association between changes in physical-activity level and other lifestyle characteristics with mortality among men. N Engl J Med. 1993;328:538-45.

4. Sytkowski PA, Kannel WB, D'Agostino RB. Changes in risk factors and the decline in mortality from cardiovascular disease: the Framingham Heart Study. N Engl J Med. 1990;322:1635-41.

5. United States, Department of Health and Human Services. Physical activity and health: a report of the Surgeon General. Atlanta: Department of Health and Human Services, 
Centers for Disease Control and Prevention, National Center for Chronic Disease Prevention and Health Promotion; 1996.

6. Ivy JL. The insulin-like effect of muscle contraction. Exerc Sport Sci Rev. 1987;15:29-51.

7. Pavlou KN, Steffe WP, Lerman RH, Burrows BA. Effects of dieting and exercise on lean body mass, oxygen uptake, and strength. Med Sci Sports Exerc. 1985;17:466-71.

8. Jones DA, Ainsworth BE, Croft JB, Macera CA, Lloyd EE, Yusuf HR. Moderate leisuretime physical activity: who is meeting the public health recommendations? A national cross-sectional study. Arch Fam Med. 1998;7: 285-9.

9. Flegal KM, Carroll MD, Ogden CL, Johnson CL. Prevalence and trends in obesity among US adults, 1999-2000. JAMA. 2002;288:1723-7.

10. Grundy SM. Multifactorial causation of obesity: implications for prevention. Am J Clin Nutr. 1998;67:563S-72S.

11. James WPT. A public health approach to the problem of obesity. Int J Obes. 1995;19:S3745.

12. Joyner MJ. Obesity and physical inactivity. Exerc Sport Sci Rev. 2000;28:49-50.

13. Koplan JP. The obesity epidemic: trends and solutions. Sports Med Bull. 2000;35:8.

14. Mokdad AH, Serdula MK, Dietz WH, Bowman BA, Marks JS, Koplan JP. The spread of the obesity epidemic in the United States, 1991-1998. JAMA. 1999;282:1519-22.

15. United States, National Heart, Lung and Blood Institute, National Institute of Diabetes and Digestive and Kidney Diseases. Clinical guidelines on the identification, evaluation, and treatment of overweight and obesity in adults. Washington, D.C.: Department of Health and Human Services; 1998. (NIH Publication No. 98-4083).

16. Andersen RE, Crespo CJ, Bartlett SJ, Cheskin LJ, Pratt M. Relationship of physical activity and television watching with body weight and level of fatness among children: results from the Third National Health and Nutrition Examination Survey. JAMA. 1998;279:938-42.

17. Hernandez B, Gortmaker SL, Colditz GA, Peterson KE, Laird NM, Parra-Cabrera S. Association of obesity with physical activity, television programs and other forms of video viewing among children in Mexico City. Int J Obes. 1999;23:845-54.

18. Hernandez B, Uphold CR, Graham MV, Singer L. Prevalence and correlates of obesity in preschool children. J Pediatr Nurs. 1998;13: 68-76.

19. Rios M, Fluiters E, Perez Mendez LF, GarciaMayor EG, Garcia-Mayor RV. Prevalence of childhood overweight in Northwestern Spain: a comparative study of two periods with a ten year interval. Int J Obes. 1999;23:1095-8.

20. Ogden CL, Flegal KM, Carroll MD, Johnson CL. Prevalence and trends in overweight among US children and adolescents, 19992000. JAMA. 2002;288:1728-32.

21. Flegal KM, Troiano RP. Changes in the distribution of body mass index of adults and children in the US population. Int J Obes. 2000;24: 807-18.

22. Troiano RP, Flegal KM, Kuczmarski RJ, Campbell SM, Johnson CL. Overweight prevalence and trends for children and adoles- cents: the National Health and Nutrition Examination Surveys, 1963 to 1991. Arch Pediatr Adolesc Med. 1995;149:1085-91.

23. Carter JS, Pugh JA, Monterossa A. Noninsulin-dependent diabetes mellitus in minorities in the United States. Ann Intern Med. 1996;125:221-32.

24. Gonzalez C, Stern MP, Mitchell BD, Valdez RA, Haffner SM, Arredondo Perez B. Clinical characteristics of type II diabetic subjects consuming high versus low carbohydrate diets in Mexico City and San Antonio, Texas. Diab Care. 1994;17:397-404.

25. Kriska AM, Knowler WC, LaPorte RE, Drash $\mathrm{AL}$, Wing RR, Blair SN, et al. Development of questionnaire to examine relationship of physical activity and diabetes in Pima Indians. Diab Care. 1990;13:401-11.

26. Stern MP, Gonzalez C, Mitchell BD, Villalpando E, Haffner SM, Hazuda HP. Genetic and environmental determinants of type II diabetes in Mexico City and San Antonio. Diabetes. 1992;41:484-92.

27. Stern MP, Haffner SM. Type II diabetes and its complications in Mexican Americans. Diabetes Metab Rev. 1990;6:29-45.

28. Batey LS, Goff DC, Tortolero SR, Nichaman MZ, Chan W, Chan FA, et al. Summary measures of the insulin resistance syndrome are adverse among Mexican-American versus non-Hispanic white children: the Corpus Christi Child Heart Study. Circulation. 1997; 96:4319-25.

29. Glaser NS, Jones KL. Non-insulin dependent diabetes mellitus in Mexican-American children. West J Med. 1998;168:11-6.

30. Neufeld ND, Raffel LJ, Landon C, Chen YDI, Vadheim CM. Early presentation of type 2 diabetes in Mexican-American youth. Diabetes Care. 1998;21:80-6.

31. McKenzie SB, O'Connell J, Smith LA, Ottinger WE. A primary intervention program (pilot study) for Mexican American children at risk for type 2 diabetes. Diabetes Educ. 1998;24: 180-7.

32. Kriska AM, Rexroad AR. The role of physical activity in minority populations. Womens Health Issues. 1998;8:98-103.

33. Crespo CH, Keteyian SJ, Heath GW, Sempos CT. Leisure-time physical activity among US adults: results from the Third National Health and Nutrition Examinations Survey. Arch Intern Med. 1996;156:93-8.

34. United States, Department of Health and Human Services. Latino community cardiovascular disease prevention and outreach initiative: background report. Washington, D.C.: DHHS; 1996.

35. Taylor WC, Baranowski T, Young DR. Physical activity interventions in low-income, ethnic minority, and populations with disability. Amer J Prev Med. 1998;15:334-43.

36. Hazuda HP, Mitchell BD, Haffner SM, Stern MP. Obesity in Mexican American subgroups: findings from the San Antonio Heart Study. Am J Clin Nutr. 1991;53:1529S-1534S.

37. United States, Census Bureau. State and county quickfacts. El Paso County, Texas [Internet site]. Available from: http://quickfacts. census.gov/qfd/states/48/48141.html. Accessed 12 November 2003.

38. Robinson L. 'Hispanics' don't exist. U. S. News World Rep. 1998 May 11:27-32.
39. United States, Department of Health and Human Services. Healthy people 2010: understanding and improving health. Washington, D.C.: DHHS; 2000.

40. Barrigüete Andreu MI, Ceballos Pozo M, Díaz Almagro MD, Pérez-Calderón RL, García Forcada L, Pérez Martín A. Prevalencia de obesidad infantil en dos poblaciones rurales. Estudio antropométrico. Aten Primaria. 1999;24: 584-8.

41. Popkin BM, Richards MK, Montiero CA. Stunting is associated with overweight in children of four nations that are undergoing the nutrition transition. J Nut. 1996;126:3009-16.

42. Rios M, Fluiters E, Pérez Méndez LF, GarcíaMayor EG, García-Mayor RV. Prevalence of childhood overweight in Northwestern Spain: a comparative study of two periods with a ten year interval. Int J Obes. 1999;23:1095-8.

43. Fanghanel G, Sanchez-Reyes L, Berber A, Gomez-Santos R. Evolution of the prevalence of obesity in the workers of a general hospital in Mexico. Obes Res. 2001;9:268-73.

44. Martorell R, Khan LK, Hughes ML, GrummerStrawn LM. Obesity in Latin American women and children. J Nutr. 1998;128:1464-73.

45. Sánchez-Castillo CP, Lara JJ, Villa AR, Aguirre J, Escobar M, Gutiérrez H, et al. Unusually high prevalence rates of obesity in four Mexican rural communities. Eur J Clin Nutr. 2001;55:833-40.

46. Must A, Dallal GE, Dietz WH. Reference data for obesity: 85th and 95th percentiles of body mass index $\left(\mathrm{wt} / \mathrm{ht}^{2}\right)$ and triceps skinfold thickness. Am J Clin Nutr. 1991;53:839-46.

47. Troiano RP, Flegal KM. Overweight children and adolescents: description, epidemiology, and demographics. Pediatrics. 1998;101:497504.

48. Winkleby MA, Robinson TN, Sundquist J, Kraemer HC. Ethnic variation in cardiovascular disease risk factors among children and young adults: findings from the Third National Health and Nutrition Examination Survey, 1988-1994. JAMA;281:1006-13.

49. Looney MA, Plowman SA. Passing rates of American children and youth on FITNESSGRAM criterion-referenced physical fitness standards. Res Quart Ex Sport. 1990;61:21523.

50. Wieller KH, Jackson AW, Meyer RD. 1-mile run performance and body mass index in Hispanic youth: passing rates for the FITNESSGRAM. Pediatr Exerc Sci. 1994;6:267-74.

51. Webber LS, Osganian V, Luepker RV, Feldman HA, Stone EJ, Elder JP, et al. Cardiovascular risk factors among third grade children in four regions of the United States: the CATCH study. Am J Epidemiol. 1995;141:428-39.

52. Luepker RV, Perry CL, McKinlay SM, Nader PR, Parcel GS, Stone EJ, et al. Outcomes of a field trial to improve children's dietary patterns and physical activity: the Child and Adolescent Trial for Cardiovascular Health (CATCH). JAMA. 1996;275:768-76.

53. Turley KR, Wilmore JH, Simons-Morton B, Williston JM, Reeds Eppling J, Dahlstrom JM The reliability and validity of the 9-minute run in third-grade children. Ped Exerc Sci. 1994;6:179-87.

54. McSwegin P, Pemberton C, Petray C, Going S. Physical best: the AAHPERD guide to physi- 
cal fitness education and assessment. Reston: American Alliance for Health, Physical Education, Recreation and Dance; 1989.

55. Goran MI. Metabolic precursors and effects of obesity in children: a decade of progress, 1990-1999. Am J Clin Nutr. 2001;73:158-71.

56. Kuczmarski RJ, Ogden CL, Grummer-Strawn LM, Flegal KM, Guo SS, Wei R, et al. CDC growth charts: United States. Adv Data. 2000; 314:1-27.

57. Centers for Disease Control and Prevention. Data and statistics. Surveys and surveillance systems [Internet page]. Available from: http://www.cdc.gov/nccdphp/dnpa/surveill. htm\#obesity. Accessed 14 February 2003.

58. Borrud LG, Pillow PC, Allen PK, McPherson RS, Nichaman MZ, Newell GR. Food group contributions to nutrient intake in whites, blacks, and Mexican Americans in Texas. J Am Diet Assoc. 1989;89:1061-9.

59. Dixon LB, Sundquist J, Winkleby M. Differences in energy, nutrient, and food intakes in a U.S. sample of Mexican-American women and men: findings from the Third National Health and Nutrition Examination Survey, 1988-1994. Am J Epidemiol. 2000;152:548-57.

60. Olvera-Ezzell N, Power TG, Cousins JH. Maternal socialization of children's eating habits: strategies used by obese Mexican-American mothers. Child Dev. 1990;61:395-400.

61. Strauss RS, Pollack HA. Epidemic increase in childhood overweight, 1986-1998. JAMA. 2001;286:2845-8.

62. Freedson PS, Cureton KJ, Heath GW. Status of field-based testing in children and youth. Prev Med. 2000;31:S77-S85.
63. Updyke WF. In search of relevant and credible physical fitness standards for children Res Quart Ex Sport. 1992;63:112-9.

64. Krahenbuhl GS, Pangrazi RP, Petersen GW Burkett LN, Schneider MJ. Field testing of cardiorespiratory fitness in primary school children. Med Sci Sports Exerc. 1978;10:208-13.

Manuscript received 4 April 2003. Revised version accepted for publication 30 December 2003.

RESUMEN Objetivo. Estudiar el sobrepeso y el acondicionamiento aeróbico en niños de tercero y cuarto grado de primaria en una ciudad de Estados Unidos de América (El Paso, Texas) y una ciudad de México (Chihuahua, Chihuahua), ambas situadas en la fron-

El sobrepeso y el acondicionamiento aeróbico en niños de la frontera mexicanoestadounidense tera entre esos dos países o cerca de ella, así como comparar los resultados observados en esas dos ciudades con resultados obtenidos anteriormente en otras muestras infantiles en Estados Unidos.

Métodos. Seguimos a un grupo de niños en El Paso (427 varones y 385 niñas, 93\% de los cuales eran de ascendencia mexicana) que cursaban el tercero o cuarto grado de primaria y evaluamos cambios en el índice de masa corporal (IMC). En la ciudad de Chihuahua medimos el IMC en una muestra transversal de niños de tercer grado (221 varones y 237 niñas) y de cuarto grado ( 268 varones y 215 niñas). A todos los niños estudiados en ambas ciudades se les tomaron mediciones de IMC y del pliegue cutáneo del tríceps. El IMC se usó para estimar el riesgo de sobrepeso (un IMC igual o mayor al del percentil 85 para la edad y el sexo) y para detectar la presencia de sobrepeso (un IMC igual o mayor al del percentil 95 para la edad y el sexo). La distancia que los niños en El Paso corrieron en nueve minutos se usó para evaluar su grado de acondicionamiento aeróbico (el cual no se midió en los niños de Chichuaua). En El Paso los datos se recolectaron en 1999, 2000 y 2001 y en Chichuahua, en 2000 y 2001. Resultados. En los varones de El Paso se observó un aumento significativo de 22 a $28 \%$ en la frecuencia de sobrepeso durante el año transcurrido entre tercero y cuarto de primaria, así como un aumento significativo de 37 a $44 \%$ en el riesgo de sobrepeso. En las niñas de El Paso se produjo un aumento significativo del riesgo de sobrepeso, de 29 a 37\%, en el mismo período de un año. Los varones y las niñas en El Paso mostraron un estado de acondicionamiento aeróbico menor, en grado significativo, que muestras de niños de ambos sexos tomadas en distintas partes de los Estados Unidos. Los niños de tercero y cuarto grado de primaria en Chihuahua mostraron tasas de riesgo de sobrepeso y de sobrepeso similares a las de los niños que cursaban los mismos grados en El Paso.

Conclusiones. Los niños en El Paso y en Chihuahua mostraron una mayor frecuencia de sobrepeso que los niños blancos que no eran hispanos en distintas partes de Estados Unidos. Los niños en El Paso mostraron un menor grado de acondicionamiento aeróbico que los niños blancos que no eran hispanos y que otros niños mexicanoestadounidenses en los Estados Unidos. Estos resultados demuestran claramente que es necesario tomar medidas en las zonas fronterizas de México y Estados Unidos para poner en marcha programas de actividad física y de nutrición orientados a frenar el aumento de la obesidad en la población. 